Abstract

As Eric Blair, the young George Orwell served in the Indian Imperial Police in Burma from 1922 to 1929, a time of growing Burmese discontent with British rule. He wrote about Burma in a novel, Burmese Days, and a number of non-fictional writings. This essay considers the nature of the law-and-order regime Orwell served in Burma, especially in the light of racial self-interest and Britain's commitment to the principle of the rule of law, and traces the issues of race and the law to his last novel, Nineteen Eighty-Four.

Keywords

Orwell - Burma - rule of law - police - Burmese Days - The Road to Wigan Pier - Nineteen Eighty-Four - British Empire - race

Word count: 9529 including notes

kerrdw@hku.hk 


\title{
Law and Race in George Orwell
}

\author{
Douglas Kerr \\ Hong Kong University
}

In October 1922, less than a year after leaving school, Eric Blair - who would take the name George Orwell ten years later - began his service with the Indian Imperial Police in Burma. He would be a policeman for five years. This essay will trace how Orwell experienced and understood the law in Burma, and how that understanding inflects all his writing. The young Blair may have thought of himself as a rebel, but his class, gender and nation made him a significant stakeholder in the status quo protected by the law. ${ }^{1}$ As a policeman in Burma he upheld British imperial law in a regime of conquest, under the sign of a rule of law which the British were unanimous in feeling was the chief benefit, and justification, of their government of other peoples. What Orwell learned in Burma about law and order had important repercussions for the development of his political views and for his future writing about power and violence, authority and privilege.

Burma, with its rich resources of oil, timber, and rice, had been added to the British Empire in the latter half of the nineteenth century for undisguisedly commercial motives. ${ }^{2}$ It was administered as a province of British India. Rangoon had long been seen as the most lawless city in the Empire, and in the years that followed the Great War there was chronic unrest in Burma, encouraged by the campaigns of Gandhi and the Congress Party in India but also by the suspicion that the concessions won 
by the nationalists from the British in India would not be equally applied to Burma. As the 1920s wore on, the Indian Civil Service (I.C.S.) officer and magistrate Maurice Collis was to report, an estrangement between British and Burmese grew more bitter, with a growing irritation among the locals at British exclusiveness. "The Burmese were treated as an inferior race; though the law was supposed to be the same for all, it was interpreted to favour the British. So the allegations went on.” ${ }^{3}$ This put extra pressure on the disciplined services whose job was to enforce the law. Sporadically there was rebellion in the air in Burma, but Assistant Superintendent Blair was the opposite of a rebel. He was a lawman. Eric Blair's experience of Burma as an officer in the Imperial Police was crucially formative of the subsequent career of George Orwell. The contradictions of the young Blair's relation to authority now played out within the larger frame of the manifest contradictions of British imperialism. For most British people their empire was a projection of their global power, a proof of the pre-eminence of their civilization, and the infrastructure of their economic well-being. At the same time many of them also thought of it as an instrument for bringing order, enlightenment, and the benefits of modernity to less favoured parts of the world.

Burmese Days, written on Orwell's return from Burma and published in 1934, is a policeman's novel, very much concerned with the law, its agents and its discontents. Its narrative climax is a riot in the fictional town of Kyauktada, where the European Club is besieged by thousands of indignant Burmese after an Englishman called Ellis has struck a Burmese boy with his stick, an attack which leaves the boy blind. The crowd want Ellis punished but, as they shout, "We know that there is no justice for us in your courts." ${ }^{4}$ John Flory, the employee of a timber company and the hero or antihero of the novel, dashes from the clubhouse, swims the river, and summons a 
contingent of military police from their nearby barracks to come and quell the mob of protestors. In an action ironically redolent of the dashing heroes of imperial romance, Flory saves the day, and law and order is restored in Kyauktada.

It is a crucial scene in many respects, but here I want to put a question about it which Orwell himself, in the novel, didn't ask. What, after all, was John Flory doing giving orders to a contingent of Indian military police, under the command of the subahdar their non-commissioned officer? I will argue that this fictional incident can reveal as much about the way things were in Burma as the rivalry between the Burmese $\mathbf{U}$ Po Kyin and the Indian Veraswami, which drives the novel's main plot. Flory is a civilian - not in the sense of a member of the I.C.S., but a person of no military experience or civil authority. No policeman in London would take orders from such a person. But in the Kyauktada riot the subahdar, ten or fifteen of his Military Police, and a Burmese police inspector, immediately spring to obey this white man whom they have probably never seen before. “'The sahib will give the order!' the subahdar panted.” (BD 263)

"Sahib" is neither a rank nor an official title, but a form by which "all over India, European gentlemen, and it may be said Europeans generally, are addressed, and spoken of, when no disrespect is intended, by natives". ${ }^{5}$ In other words, it is an ethnic designation, and Flory's race is the trump card that overrules all other hierarchies when he is among non-Europeans. This assumption of command is so thoroughly naturalized that nobody appears to question or think about it. ${ }^{6}$ Trapped with the other Europeans in the Club, Macgregor the Assistant Commissioner and senior colonial official has been fretting at the uselessness of the police nearby, without a British officer to lead them. Just as the Burmese population had been 
disarmed by colonial order since the early days of the occupation of Upper Burma, ${ }^{7}$ the Indian sepoys are a disciplinary force whose capacity for decisive action seems to be paralysed, until a European tells them what to do. The police control the Burmese, but they take their orders from the British, commissioned or not.

Flory's action, which is considered heroic by the British community in Kyauktada, and indeed reads like a cliché from an adventure story for boys, helps to illustrate the special nature of the rule of law in the British Empire which it was Eric Blair's job to police. The rule of law was almost universally agreed to be the special characteristic and unique justification for Britain's imperial government.

Indeed, by the time of the impeachment of colonial India's first governor-general, Warren Hastings, in the 1780s, government by law was already becoming the privileged basis for the conceptualization of the "moral legitimacy" of British colonialism. The ideological justification for the British presence in India drew heavily on a much-vaunted tradition of ancient English liberty and lawfulness. ${ }^{8}$

The law had to be even-handed. "I have never wavered in a strict and inflexible justice between the two races," Lord Curzon, Viceroy of India, wrote to Lord George Hamilton on September 23, 1903. "It is the sole justification and the only stable foundation for our rule." ${ }^{9}$ J. S. Furnivall, a former I.C.S. officer, endorsed this argument for the legitimacy of British empire: "Our government is based on the western principle of the rule of law, and in that respect may justly be claimed as superior to the Burmese system." ${ }^{10}$ And Maurice Collis, another I.C.S. man, serving as District Magistrate of Rangoon, took comfort in the same belief. "The law of England is admired the world over, and it is on the excellence of its practice that our moral right to be in India is founded." ${ }^{11}$ Not surprisingly, that loyal Indian imperialist 
Dr Veraswami in Burmese Days shares this faith in "unswerving British justice and the Pax Britannica" (BD 40). The foundation of the British Empire upon law was especially vaunted in Asia, where, as Western observers from Montesquieu to Marx agreed, the native forms of government were typically despotic. Government in the Indian Empire and in British colonies was bound by the law, whose rules were applicable to all, and its officials acted within legal restraints. And when the time came, the rule of law was offered as the most valuable legacy of departing British government to its postcolonial successors, conceptualized as "the gift we gave them". ${ }^{12}$ In the eyes of both liberal and conservative imperialists, it was above all through the rule of law that empire conferred modernity on its subject peoples and their heirs.

The subjects of Britain's second or nineteenth-century empire consisted mostly of people who were not slaves, but not quite free either. This empire had to rest on the idea of a sovereignty that was neither despotic nor democratic, but was law-abiding. No doubt there is always a tension between political exigencies and legal rule, between the orders of the sovereign and the rule of the law. In a rule-of-law regime, one function of the law is to limit the very forms of power that make it possible. ${ }^{13}$ District Superintendent Westfield in Burmese Days, who is always grumbling at the way "law" gets in the way of "law and order", is a good example of this contradiction. In a place like Burma, the very conditions that made legality "the pre-eminent signifier of state legitimacy", as Nasser Hussain puts it, made it almost impossible for the law to extend its equal protection to all. ${ }^{14}$ "The colonial rule of law purported to treat all subjects equally," says Elizabeth Kolsky, "but it did not (and could not) do so given its fundamental involvement in the entrenchment and protection of British power." ${ }^{15}$ For beneath the institutions of the rule of law ran an ideology of racial 
difference that insisted - anticipating the last Commandment of Animal Farm - that some people were more equal than others. ${ }^{16}$

Amitav Ghosh, whose The Glass Palace (2000) is a historical novel of Burma, has argued that Enlightenment and liberal ideas, including the rule of law, have to be understood in light of the important if unacknowledged place that the idea of race occupied in their conception. In published correspondence with Dipesh Chakrabarty, Ghosh describes race as the "silenced term" in liberal thought.

In this sense, one of our tasks surely, must be to restore, always and without flinching, the silenced term in the equation - the ' $+\mathrm{R}$ ' as I have come to think of it. Thus in British India, 'the rule of law' is actually 'the rule of law + R' and since legal procedures differed significantly when applied to Indians and British, this does in fact yield a much more accurate picture of the functioning of the legal system of British India than the unqualified term. ${ }^{17}$

The liberties protected by law had always been limited for persons thought to be incapable of self-determination, a list of exceptions that had at various times included children, mental incompetents, women, slaves, and colonized subjects. ${ }^{18}$ Maurice Collis, who did his best to treat everyone fairly from the magistrate's bench and was criticized and eventually removed for doing so, confessed that "during our occupation of Burma" there was not a real equality before the law. "In spite of declarations to the contrary we had placed English interests first, and we had treated the Burmans not as fellow creatures, but as inferior beings." ${ }^{19}$ Collis reported the British Governor of Burma, Sir Reginald Craddock, reprimanding an English lecturer at Rangoon College who had married a Burmese woman. "The implication was that you were lowering British prestige; the Burmese would think less of us if we did not 
treat them as inferiors.” "The Burmese were treated as an inferior race," wrote Collis, and the consequence was a widespread belief that "though the law was supposed to be the same for all, it was interpreted to favour the British". ${ }^{21}$ To be sure, within the category of 'Burmese' there were further hierarchies, in British eyes, of race and caste and class. An Oxford-educated Burmese lawyer was regarded quite differently from a Burmese police constable and differently again from a Karen peasant. But in general terms, racial prestige spoke louder than law, just as the racial authority of the white civilian Flory trumps the official authority of the Indian police officer in the Kyauktada riot. These particular conditions bring extra stress to bear on a question that faces any police force, or police officer. Whom do the police serve: the courts, or the government? Law or power?

Superintendent Westfield in Burmese Days embodies this dilemma to perfection. He is a conscientious officer, proud of his men. He upholds the law. But in the sanctuary of the European Club he expresses his views freely, grumbling about the way his hands are tied by red tape - bureaucratic legality - and affronted that "the natives know the law better than we do" (BD 30). This was a complaint heard all over British India, and shortly the rest of the Empire, with the appearance of the cohort of trained lawyers, like Gandhi and Nehru and Sen Gupta, who were in the vanguard of anti-British nationalist movements. In Burmese Days the out-and-out racist Ellis, a civilian, urges that the British have got to hang together and say "We are the masters", but Westfield responds gloomily that this is impossible. Although in self-conception the servant of British mastery, professionally he is the servant of British law. "It's all this law and order that's done for us," says this unlaughing policeman (BD 29, 30). Later when Ellis proposes the torture of some villagers to extract information, Westfield again demurs. "But that won't do nowadays. Got to keep our own bloody silly laws." (BD 
250) Burmese Days is fiction, of course, and cannot be held to account for strict historical accuracy. But Orwell told F. Tennyson Jesse that much of the book was "simply reporting of what I have seen". ${ }^{22}$ Westfield's grouses seem to register accurately a state of mind widespread among long-serving British officials and unofficials alike that the real business of protecting British interests was annoyingly compromised by British law itself, increasingly irksome with the introduction of the dyarchy reforms. "We seem to have no authority over the natives nowadays, with all these dreadful reforms," sighs the Englishwoman Mrs Lackersteen. (BD 26) In private, Westfield could not agree more. When he dreams, he dreams of the escape from these constraints which, he feels, would follow a worsening of the situation and the declaration of a state of emergency. The patron saint of this state of mind is General Dyer, relieved of his command after ordering the massacre of hundreds of unarmed protestors at Amritsar in 1919, a martyrdom (Dyer's) spoken of in reverent tones in the Kyauktada Club. "If a rule of law was the settled theoretical standard of colonial politics," Nasser Hussain maintains, "the institutional practices of the colonial state constantly fell short of such a standard." ${ }^{24}$

Westfield and the other members of the whites-only Club (and Blair) inhabit the reality of the rule of law in a racialized political system, in a regime of conquest. The operation of the law may be conceived as universal, formal and rational, but in practice to uphold law and order in British Burma was to serve the interests of a racial oligarchy, and it was a practice as ideological as it was legal. ${ }^{25}$ The disciplinary forces were the sharp end of the enterprise. Orwell was to recoil from this work, which he saw as servicing the machinery of despotism: British or French, "economically it is just the usual swindle for which empires exist". ${ }^{26}$ As in the rather similar case of Leonard Woolf, who resigned from the Ceylon Civil Service in 1912, it is hard to tell at what 
point Orwell arrived at the mature critique of imperialism which came to shape his political character. ${ }^{27}$ But Flory, in his conversation with his friend Veraswami, has got as far as asking the question what that despotism is for. Veraswami enthuses over the law and order that goes under the name of the Pax Britannica: Flory calls it Pox Britannica, and says it serves the money-lender and the lawyer - "More banks and more prisons - that's all it means" $(B D 40) .^{28}$

Flory's employers could have told him who profited most from the British possession of Burma, which brought the Empire little strategic gain but was commercially very lucrative. ${ }^{29}$ The heads of large foreign businesses, according to Furnivall, were content that the Government should maintain law and order and leave everything else to the play of economic forces in a game which was stacked in their favour; and in any case they were the agents of shareholders, mostly overseas, whose attitude to the country was purely extractive. "That was the attitude also of the Indian and Chinese sojourners, down to the humblest coolie who came to Burma for a few months to earn higher wages than he could get at home. All these interests may be summed up as capitalist." ${ }^{30}$

Maurice Collis could see that by the end of the 1920s, "Every man and woman in Burma wanted to get rid of the English government, not because it was oppressive or lacking in good qualities, but because its policy was pro-English instead of being pro-Burman.” ${ }^{31}$ The government, said Collis, had two faces. One face was benevolent and paternal, the other that of a businessman. "As British mercantile interests were put first, how could the other policy ever come to anything?" ${ }^{2}$ Was an official like himself the representative of British civilization and progress, or an agent whose duty consisted in promoting British commerce? Collis himself became 
unpopular with his compatriots when, giving judgement in the trial of an English employee of the merchant firm Steel Bros accused of torturing his servant to extract a confession of theft of a pair of sleeve-links, he rebuked the accused for "an extraordinary insensibility to the proprieties of ordinary human intercourse". ${ }^{33}$ Later Collis outraged the army and the European business community when he convicted an officer in the Camerons of criminal negligence, after he ran a red light and grievously injured two Burmese women, and sentenced him to three months' imprisonment and a fine. ${ }^{34}$ The sentence was overturned on appeal to the High Court, and soon afterwards Collis was promoted to Excise Commissioner and thus removed from the bench. In his memoirs Collis himself is never cynical, but his experiences seem to confirm much of Flory's sarcastic view of British law and order and the Pox Britannica in Burma.

It was not only actions of the agents of law, and other officials, that in practice fell short of the theoretical standard of colonial politics propounded by high officials like Curzon. Elizabeth Kolsky, in her study of the painful bodily experience of the Raj, argues that white violence was not exceptional but an everyday part of British rule in the subcontinent, and routinely went unpunished. "The colonial promise of legal equality was blatantly undermined by the institutionalization of race-based legal privileges and by the discriminatory practices of police, judges, and juries that consistently tipped the scales of justice." ${ }^{35}$ Most of Kolsky's examples are from the nineteenth century, and perpetrated by white planters, soldiers, and seamen - the lower orders of British colonial society. ${ }^{36}$ But a reading of Burmese Days shows a remarkable level of everyday and unchecked violence on the part of Europeans in 1920s Burma. Orwell himself confessed to hitting servants and coolies with his fist, as "nearly everyone" does in the East, since "orientals can be very provoking". ${ }^{37}$ No 
doubt one aspect of what he later called "the disgusting social behaviour of the British [in Burma] till very recently”, the licence for such conduct was racial. ${ }^{38}$ In Britain after the Great War, nobody could have expected to punch a servant or workman without risking repercussions.

The Club butler in Burmese Days is a Dravidian, not a Burmese, but his ethnicity gives him no protection. He is treated like a serf. The Club members routinely yell and swear at him, and Ellis abuses him for speaking good English, and thus trespassing impertinently on the cultural property of his masters. Later Verrall, a British officer in the military police, kicks the old man on their first encounter for serving him a warm whisky, and is quite unrepentant when upbraided by Ellis.

Ellis turned quite grey. He was furious. The butler was a piece of Club property and not to be kicked by strangers. But what most angered Ellis was the thought that Verrall quite possibly suspected him of being sorry for the butler - in fact, of disapproving of kicking as such. (BD216)

Macgregor, the senior official in Kyauktada and represented as being quite sympathetic to "natives", remembers fondly the good old days when, if one's butler was disrespectful, "one sent him along to the jail with a chit saying 'Please give the bearer fifteen lashes"' (BD 27). It is one of the old fool's favourite anecdotes, and an instance of the way the disciplinary services could be thought of as being there to reinforce not the rule of law but the authority of race, while the casual order to inflict corporal punishment - we might reflect what fifteen lashes might actually do to the body of the person receiving them - indicates as well as anything the assumption that the boundary of race divided two kinds, and two orders, of human being. Beneath the superstructure of the rule of law, and over-riding it on occasion, lay a basic belief in a hierarchy of race. The letter of the law might be reformed from time to time, as when 
dyarchy was introduced to Burma in 1923, the year after Blair's arrival. But the racial hierarchy was inscribed on the body and was unalterable. Orwell's later writing may be another story, but Burmese Days gives no reason to suppose this situation can ever be changed. In Kyauktada, Burmese (and Indian) subaltern subjects are happy to benefit from British patronage and favours, and the resistance is hopelessly ineffectual.

It was a state of affairs that could produce a strange kind of intimacy between the powerful and the powerless, a topic which has been explored by Ashis Nandy. ${ }^{39}$ In Burmese Days, Flory has purchased his mistress Ma Hla May from her parents for three hundred rupees. Although in fact his slave, she enjoys her position in his household and puts love philtres in his food to retain his affection. When she displeases him he threatens to beat her with a bamboo, and the scene of his rejection of her, when she abases her body and creeps "wormlike" on his floor, is the most terrible in the novel (BD 160). Orwell remembered allowing himself to be dressed and undressed by his Burmese boy, noting that he would never have endured to let an English manservant do this, and wrote enthusiastically about the beauty of the Burmese, their firm-knit silken skin, excellent teeth, and beautiful bones. ${ }^{40}$. Yet when he lost his temper he was capable of beating them without compunction.

The enslavement of Ma Hla May in Burmese Days, and the beatings, were against the law, though this is not remarked. In the sphere of domestic and bodily intimacy, orders could over-rule laws. These things belong to the disquieting politics of the body in Orwell's novel. Words like 'sedition' and 'rebellion' convey to the mind of Mrs Lackersteen "a picture of herself being raped by jet-black coolies with rolling white eyeballs" (BD 142). ${ }^{41}$ Her niece Elizabeth Lackersteen, dimly remembering some magazine article about Lombroso, thinks the shape of the Burmese skull indicates 
wickedness, while Flory tries to persuade her that the agility of Burmese dancers speaks to an immemorial refined civilization $(B D 122,107)$. Here we can see the two faces of the Orientalist vision - the savage and dangerous Orient, and the civilized, picturesque and unchanging Orient - embodied in the modern Burmese colonial subject under Western eyes.

Membership of the racial oligarchy made every Englishman in the East semi-official, as is acknowledged by the immediate obedience of the police to the orders of Flory, a civilian. Even for reluctant recruits like Flory himself, or the unwilling murderer of the elephant in "Shooting an Elephant", or the young Superintendent Blair who shared his mutinous thoughts in secret with a stranger encountered on a night-time train journey to Mandalay, ${ }^{42}$ his race for an Englishman was the visible badge of his conscription in the unofficial "army of unalterable law" - a phrase that depressed Orwell - which kept his own kind in power, and the locals under control. ${ }^{43}$

There were actual emergencies in colonial Burma, such as the rebellion of Saya San in 1930 which was in its second year as Orwell, returned to England, was writing Burmese Days. Such crises demanded that Europeans in Burma, civilian and military, forget differences among themselves, and stand together like the Club members besieged in the Kyauktada riot. In a similar way in E. M. Forster's $A$ Passage to India, the crisis of Adela Quested's reported assault by Dr Aziz immediately creates a stockade mentality among the British, reminding them ominously "that they were thousands of miles away from any scenery that they understood". ${ }^{44}$ There are demonstrations proclaiming the innocence of Aziz, and something like a riot, but martial law is not invoked in Chandrapore at this time of crisis. Even so there is great indignation among the British because the apparent victim of the assault is an English woman, and the apparent perpetrator an Indian, 
and this is compounded by the news that an Indian magistrate is to preside at the trial of Aziz. ${ }^{45}$ Several European women send a telegram of complaint to the wife of the Lieutenant-Governor, another instance - this time a gendered one - where it is assumed that race must trump the normal process of law.

Yet even in what passed for ordinary times, there was not really an opt-out from colonial identity and solidarity, and the obligations and privileges of the racial authority or "prestige” that went with it. Flory's feelings for local people are a great deal warmer than for his fellow countrymen, all of whom he despises. Yet he has to admit to himself that he is "a creature of the despotism, a pukka sahib, tied tighter than a monk or a savage by an unbreakable system of taboos" (BD 70). Dr Veraswami is his only friend, yet he knows that he is bound to betray him. "There's no law telling us to be beastly to Orientals - quite the contrary. But - it's just that one daren't be loyal to an Oriental when it means going against the others.” (BD 151) Over-riding the law that mandates equality is the pukka sahib's code, which dictates the actions and opinions of a white man in the East. Under this discursive regime anticipating Nineteen Eighty-Four - friendship can hardly exist, and "Free speech is unthinkable" (BD 69).

The rule of law was the fundamental argument justifying British government over Oriental peoples who, the argument went, had known nothing but the rule of arbitrary despots. The principle of the rule of law is that governments and their functionaries may not act illegally. In ordinary circumstances the law is paramount in a rule-of-law regime, and applies equally to all, but not in all circumstances. The subordination of rules to orders is the defining characteristic of martial law, declared in times of emergency, and involving the suspension of some of the protections of 
the law in the name of security. ${ }^{46}$ Yet it seems that often in the sphere of domestic conduct, and more importantly in the minds of most of the colonial personnel whom Blair knew and Orwell wrote about, the subordination of law to order was permanent, as if in an undeclared and never-ending state of emergency, and members of a self-appointed oligarchy maintained their control with a licence to do violence to people with no power to resist them. In these quite specific ways, Burmese Days rehearses Nineteen Eighty-Four.

In the remaining part of this essay, I want to consider some points in which Orwell's memory and representation of questions of law and order, race and violence, seem to be carried over and developed from the Burmese writing to the entirely European world of Nineteen Eighty-Four. It is important, though, to avoid the common reductive mistake of viewing all of Orwell's career as moving teleologically towards the achievement of his last book. Nineteen Eighty-Four happens to be the last work in Orwell's bibliography of publications, but in no other sense is it a last word, a summary or culmination of his earlier writing, still less of his lifetime's experience. With this significant caveat, it is worth considering the relation between Orwell's first novel and his last, in their depiction of the workings of the disciplinary state.

In a rule-of-law regime, the state is governed by law, and the police enforce the law with discipline. British Burma was nominally a rule-of-law regime, but the law itself unjustly favoured a racial oligarchy whose privileges were maintained by the punitive regulation of others by the disciplinary forces (civil and military police, prisons etc). In the dystopia of Oceania in Nineteen Eighty-Four, the law itself has dropped out of the frame. In Oceania nothing is illegal, since there are no longer any laws. ${ }^{47}$ In a permanent state of emergency justified by a permanent state of war, the police have 
unbridled powers to enforce the will of the Party-state (Ingsoc and Oceania elided) through discipline and violence. ${ }^{48}$ It is envisaged that in future the formula will be simpler still, and the relationship between the state and disciplinary violence will be tautological - "imagine a boot stamping on a human face, for ever" (NEF 280). This vision of the future entertained by Winston Smith's torturer O'Brien is itself trumped, however, by the way the end of history is imagined by Ingsoc, a mad dream which is set out in the book's Appendix on "The Principles of Newspeak". Once behaviour and thought are regulated through Newspeak, and disobedience has become literally unspeakable and therefore unthinkable, there need be no police, just the state, its discipline fully introjected through the language. Oceania in 1984 (if it is 1984: Winston Smith is not sure), with its regular gendarmerie and its Thought Police, is a staging post on the road to the really absolute power of the Party which is the state.

A number of interesting continuities can be picked out between the colonial world of Kyauktada in the Burma of Burmese Days and the tyrannical world of London in the Oceania of Nineteen Eighty-Four. ${ }^{49}$ The future London is a segregated space. A British colonial town in the East would have its sprawling native quarter separate from its military and civil "lines", or "Civil Station" centred on the European Club. Winston Smith's London too is zoned, and it is as rare and risky for him, as an Outer Party member, to penetrate into the quarter of the town where the Inner Party members have their luxury apartments, as it is for him to wander among "the vague, brown-coloured slums" where the proles live (NEF 175, 85). Police patrol the prole districts but generally their inhabitants are left to their own devices unless there is a disturbance of the peace. The proles speak their own language, a kind of Cockney which is always orthographically marked as deviant from the more educated English 
of Winston Smith, his colleagues, and the novel's narration. When Winston enters a pub, he is awkward as a foreigner, and is treated with suspicion by the locals. At the same time, like Flory with his visits to Veraswami, he is risking his own prestige. "As usual, there were no definite rules against talking to proles and frequenting their pubs, but it was far too unusual an action to pass unnoticed.” (NEF90)

Denigratory generic statements about the proles are forever being made, often offhand, by Winston and his Party colleagues. Proles are certainly not rights-bearers, and are entirely excluded from government or any other authority. "Proles and animals are free,” runs a cynical Party slogan (NEF75), suggesting the proles are a biological category like a race rather than an economic category like a class. "The proles are not human beings," says the lexicographer Syme, speaking "casually", assuming consent (NEF 65). When thinking about the proles Winston Smith himself is prone to what Edward W. Said called "radical typing", the name Said gave to the assumption that every Oriental always acts according to and in confirmation of type. ${ }^{51}$ Later in the novel, when he has invested all hope for political change in the proles, Winston is inclined to sentimentalize and idealize them, the "mystical reverence" he feels for the singing prole woman, just before his arrest (NEF 229), having some similarity with Flory's tour-guide panegyric on the Burmese pwe-dance: Flory finds the dance grotesque and ugly, and yet "when you look closely, what art, what centuries of culture you can see behind it!” (BD 107).

Like Burma, Oceania is governed by a sequestered oligarchy, and the majority of its population are excluded from political life unless, as Winston piously hopes, they rise in rebellion at some future date. Yet of course the Oceanian proles are a class, 
not an ethnic group. In the novel the point is made firmly that the disciplinary state in Oceania is not racial but political. While all named characters in the story seem to be white English-speaking Europeans, there is specifically no racial discrimination, and no Oceanians feel that they are a colonial population ruled from a distant capital (NEF 217). The hegemonic Party is open to all ethnicities, and presumably so is the resistance, embodied in the Brotherhood (if it exists). So in what might be called its manifest content, Nineteen Eighty-Four is not about race, and in this respect seems to owe much more to the incipient police state in Barcelona in 1938, described in Homage to Catalonia, than to John Flory's, Eric Blair's, or George Orwell's Burma.

There is however another dimension to the novel which is an oneiric or unconscious plot, which plays out in a combination of Winston Smith's dreams, fantasies and memories. This other plot punctuates the events of the story, or the novel's story of events. In this parallel fictional universe, the master trope is the process of dreamwork condensation, in which one image filmically dissolves into another. Here in the poetic or unconscious plot, the story of racial oppression and violent injustice is very much alive. It can be traced by following two images which seem to have their origins in Blair's memories of his days in the Burma police - the image of the victim of physical violence, and the image of the unjustly treated prisoner. They are often embodied in the same person, and both are instantiated, of course, in the emiserated body of Winston Smith himself, imprisoned and tortured in the Ministry of Love in the latter part of the novel. But they can earlier be traced as master images of the oneiric plot. 
In the opening chapter of Nineteen Eighty-Four, Winston Smith sits down to start writing in his diary, but cannot think where to begin. After some time staring stupidly at the blank paper, he suddenly begins writing in sheer panic, only imperfectly aware of what he is putting down on paper. This semi-automatic writing is an account of a visit to the cinema the previous evening, when he watched a war film in which a ship full of refugees was bombed somewhere in the Mediterranean. ${ }^{52}$ In a lifeboat full of children, he recalls in his breathless prose in the diary, "there was a middleaged woman might have been a jewess sitting up in the bow with a little boy about three years old in her arms".

little boy screaming with fright and hiding his head between her breasts as if he was trying to burrow right into her and the woman putting her arms round him and comforting him although she was blue with fright herself, all the time covering him up as much as possible as if she thought her arms could keep the bullets off him. (NEF 10)

This incident, greatly enjoyed by most of the cinema audience, is a familiar instance of the helpless vulnerability of the body to the machine (in this case, a machine-gun). Machine-gunning civilians was a war crime. The tentative specification of the woman as Jewish is of great interest. ${ }^{53}$ With the imperilling of European Jewry and moves to create a Jewish homeland in Palestine, there were Jewish refugees attempting to make a Mediterranean passage to Palestine throughout the 1940s, and British naval efforts to control this traffic were very much in the news at the time when Orwell was writing Nineteen Eighty-Four. ${ }^{54}$ But here in any case is the first appearance in the novel of a motif we can call the Madonna-and-child group, and notably it is not only gendered but also racialized. 
Winston does not know what has made him write about this film in his first diary entry. But it has the unexpected effect of triggering a totally different memory in him, of something that had happened that morning, and this is narrated next, though he does not enter it into the record of his diary. It is the convening in his workplace of the daily Two Minutes Hate, when the "lean Jewish face" (NEF 14) of Emmanuel Goldstein, the Enemy of the People, is projected on the telescreen, and hysterically vilified by the audience. The satanic outlaw Goldstein - "the primal traitor" ( NEF 14) - is based on Leon Trotsky, and this is sufficient explanation for his Jewish name and appearance, though association with the Jewish woman in the lifeboat must have played a part in bringing this memory to Winston's mind. On screen, the face of the Jew Goldstein dissolves into the demonized Oriental enemy, the army of Eurasia with which Oceania is currently at war, before being cinematically vanquished as "the hostile figure melted into the face of Big Brother, black-haired, black-moustachio'd, full of power and mysterious calm" (NEF 18). The audience at the Hate chant the leader's name in a general delirium, but Winston has recoiled in secret horror, and, while replaying this memory in the evening, realizes that his unconscious has declared his own allegiance. "He discovered that while he sat helplessly musing he had also been writing, as though by automatic action.” (NEF 20) What he has written - DOWN WITH BIG BROTHER, in capital letters, four times repeated - states his resistance to the all-powerful nom du père (or du frère) but simultaneously dooms him to victimhood, for he knows that resistance is futile and in starting his diary, if not before, he has committed a serious thoughtcrime and signed his death warrant. By unconscious promptings and dreamwork condensation, Winston Smith has enrolled, with the Jewish refugee and the Jewish renegade and the Oriental other, in a cause as hopeless as the gesture of a mother in trying to use her body to protect her child from a helicopter gunship. 
The Madonna-and-child group makes its next appearance again through the unconscious, when Winston has a dream in which he sees his own mother "sitting in some place deep down beneath him, with his young sister in her arms," apparently in the saloon of a sinking ship. The death by water of this Madonna links the dream to the memory of the Jewish woman in the lifeboat, and Winston, intuiting in his dream that in some way the lives of these female victims have been sacrificed to his own, now realizes that his mother's death, nearly thirty years before, had been tragic and sorrowful in a way that was no longer possible, belonging as it did "to the ancient time, to a time when there was still privacy, love and friendship, and when the members of a family stood by one another without needing to know the reason" (NEF 32). His own mother's death is associated with the helpless gesture made by the Jewish mother in the lifeboat, to protect her child. In the novel's oneiric plot these images are not linked by logic or by narrative, but poetically, by association. It is no accident that these images arrive in oneiric and in cinematic form. The filmic trope of the dissolve is a species of metonym at the centre of which is a moment of Schrodingerian superposition when, for example, the image is both the Jewish refugee and Winston's mother. ${ }^{55}$ Yet clearly what is being assembled here is a congeries of ideas that make up the opposition to the army of unalterable law, ideas doomed to fail in the face of an omnipotent authority wielding unlimited violence, but nonetheless worth dying for. Curiously, although in the manifest story the Party is unconcerned with race, in the oneiric plot that opposition includes a racial coding.

The Madonna-and-child group reappears next in another dream, in which Winston seems to review his whole life, taking place within the glass paperweight he has 
purchased from Charrington's shop. Waking, he feels that the whole dream is comprehended by "a gesture of the arm made by his mother, and made again thirty years later by the Jewish woman he had seen on the news film, trying to shelter the small boy from bullets" (NEF 167). It becomes clear that in this dream he has been remembering his very last glimpse of his mother, drawing her arm protectively round Winston's baby sister as Winston himself, after stealing chocolate from the small dying child, fled down the stairs. He had returned hours later to find his mother and sister gone, taken away by the police, perhaps to a forced-labour camp, certainly to their eventual death.

The dream was still vivid in his mind, especially the enveloping, protecting gesture of the arm in which its whole meaning seemed to be contained. His mind went back to another dream of two months ago. Exactly as his mother had sat on the dingy white-quilted bed, with the child clinging to her, so she had sat in the sunken ship, far underneath him and drowning deeper every minute, but still looking up at him through the darkening water. (NEF 171)

Through the maternal gesture, the mother in the dingy apartment is identified with the mother in the sunken ship, and with the Jewish mother in the lifeboat. Winston's dying sister, from whom he steals food, is aged three, the same age as the refugee child machine-gunned in the lifeboat. The aggressor from whom the mother ineffectually shields her baby is Winston himself: he has seized his sister's chocolate ration, and then abandoned the two females to their fate, never to see them again. ${ }^{56}$ But here the dreamwork has been busy in its work of condensation. The maternal avatar, with her protective gesture, is trying to shield her daughter, but in the figure of the Jewish refugee, the same gesture attempts to protect the son, that is, Winston. Winston is, in his own mind, the betrayer and killer of his mother and sister. But if he is the murderer of his mother, he is also her child, the son of a Jewish mother - 
Jewish according to the associative logic of dream - and therefore himself a Jew. In this novel of the nineteen-forties it is an association that gives a strong extra poignancy to his later long humiliation and torture in the Ministry of Love, with the sense that he is both a lifelong functionary of the Party and beneficiary of its meagre privileges, and a person whose race - that is, whose body - has destined him all along for injustice and suffering at the hands of the Party's inhuman machinery. In this way the racial theme has an underground presence in Nineteen Eighty-Four, as does the conflicted structure of feeling inhabited by Eric Blair in Burma, and incipient in the schoolboy responding to "Lucifer in Starlight" and its renegade predestined to defeat by the army of unalterable law.

To Orwell - to any European - in the nineteen-forties, the most immediate example of systematic racism was not for the moment in the European empires in Asia or Africa but in the fate of the Jews of Europe..$^{57}$ The Asian theme does have a presence in the novel, however. During the Two Minutes Hate, behind the renegade Goldstein's image on the telescreen are seen marching endless columns of the Eurasian army, "row after row of solid-looking men with expressionless Asiatic faces" (NEF 15). Later in the film, Goldstein's face dissolves into the hostile figure of a Eurasian soldier. Oceania has two alternating enemies, Eurasia and Eastasia. The Eastasians are clearly Japanese and Chinese, and Eurasia is recognizably based on the Russian-led Soviet Union. ${ }^{58}$ But every time a Eurasian person appears in the novel, their "Asiatic" or "Mongolian" appearance is noted. ${ }^{59}$

Both Oceania's serial enemies are Oriental. Party propaganda makes much of the danger they pose, but this danger is never seen (and may be imaginary anyway). 
"Foreigners, whether from Eurasia or from Eastasia, were a kind of strange animal. One literally never saw them except in the guise of prisoners, and even as prisoners one never got more than a momentary glimpse of them." (NEF121) In a description of some such prisoners, we may get a momentary glimpse of our own, of the memory of the jails in Burma that haunted Eric Blair. In Victory Square, Winston Smith witnesses the passing of a column of trucks full of squatting prisoners of war, their "sad Mongolian faces" staring incuriously about them. ${ }^{60}$ The face, once again, is a register of helpless victimhood. Here is an explicit racial antagonist, disciplined and reduced to a figure of abjection. One face in particular strikes Winston.

In the last truck he could see an aged man, his face a mass of grizzled hair, standing upright with wrists crossed in front of him, as though he were used to having them bound together. (NEF 122)

The upright posture signals resistance, the crossed wrists indicate enslavement. Winston Smith watches this tragic stranger pass in the company of his lover Julia, a free spirit and the only ally of his secret rebellion. In one last oneiric superposition she in turn is orientalized and rendered abject, offering an unheeded prophecy of the punishment that awaits them both.

With hands locked together, invisible among the press of bodies, they stared steadily in front of them, and instead of the eyes of the girl, the eyes of the aged prisoner gazed mournfully at Winston out of nests of hair. (NEF 123)

It is a moment of no importance to the manifest plot of Nineteen Eighty-Four. But in the oneiric story, and in the story of Orwell's long engagement with questions of law and race, it is an elision of two figures with no rights before the law - the racial victim and the ideological renegade, helpless sufferers from past and future violence. 
This work was supported by the Hong Kong Research Grants Council under grant no. H743713.

\footnotetext{
1 The development of the structure of feeling Eric Blair shared with his class and generation is traced in a late autobiographical essay about his schooldays, "Such, Such were the Joys", in The Complete Works of George Orwell, ed. Peter Davison, 20 vols. (London: Secker and Warburg, 1998) XIX:356-87). Subsequent references to the Complete Works are indicated by volume and
} page numbers.

${ }^{2}$ For the history of modern Burma I have drawn on J. S. Furnivall, Colonial Policy and Practice: A Comparative Study of Burma and Netherlands India 1948 (New York: New York University Press, 1956), Maung Htin Aung, A History of Burma (New York: Columbia University Press, 1967), Thant Myint-U, The Making of Modern Burma (Cambridge: Cambridge University Press, 2001), Michael W. Charney, A History of Modern Burma (Cambridge: Cambridge University Press, 2009), Ian Brown, Burma's Economy in the Twentieth Century (Cambridge: Cambridge University Press, 2013).

${ }^{3}$ Maurice Collis, Into Hidden Burma: an Autobiography (London: Faber and Faber, 1953) 165.

${ }^{4}$ George Orwell, Burmese Days, 1934 (London: Secker and Warburg, 1986) 257. Subsequent references to this novel are indicated parenthetically in the text as $B D$.

${ }^{5}$ Henry Yule and A. C. Burnell, Hobson-Jobson: The Anglo-Indian Dictionary, 1886 (Ware, Hertfordshire: Wordsworth Editions, 1996) 781-82.

${ }^{6}$ Blair's police training would have included detailed instructions for procedure when confronted with an unlawful assembly. If no magistrate was available when public security was manifestly endangered, “any commissioned officer of Her Majesty’s Army may disperse such assembly by military force”. The Abridged Law Manual for Sub-Inspectors of Police (Rangoon: Supdt., Government Printing and Stationery, Burma, 1925) 146. Flory does not hold a commission and so 
is not authorized to take command in the riot. (Although this part of the Abridged Law Manual seems to be of Victorian date, it was included in the Manual of 1926.)

See J. S. Furnivall, Colonial Policy and Practice, 181. The fact that the local population are not allowed firearms is a significant factor in the tension described in "Shooting an Elephant" (X: 501-6).

${ }^{8}$ Nasser Hussain, The Jurisprudence of Emergency: Colonialism and the Rule of Law (Ann Arbor: University of Michigan Press, 2003) 3.

9uoted in David Gilmour, Curzon: Imperial Statesman (New York: Farrar, Strauss and Giroux, 2003) 166. Though Curzon's belief in the rule of law was sincere, people came to discern features of Asiatic despotism in his own style of government, and "friends jokingly called him Akbar" (152).

${ }^{10}$ Furnivall, Colonial Policy and Practice, 175.

"Maurice Collis, Trials in Burma (London: Faber and Faber, 1938) 135.

${ }^{12}$ Sally Engle Merry, "Review: Law and Colonialism," Law \& Society Review 25:4 (1991) 890.

${ }^{13}$ See Merry, "Review: Law and Colonialism", 896-97.

${ }^{14}$ Hussain, The Jurisprudence of Emergency, 4.

${ }^{15}$ Elizabeth Kolsky, Colonial Justice in British India (Cambridge: Cambridge University Press, 2010) 210.

${ }^{16}$ "All Animals Are Equal But Some Animals Are More Equal Than Others." George Orwell, Animal Farm, 1945 (London: Secker and Warburg, 1987) 90.

${ }^{17}$ Amitav Ghosh and Dipesh Chakrabarty, "A Correspondence on Provincializing Europe," Radical History Review 82 (2002) 148.

${ }^{18}$ See Brian Z. Tamanaha, On the Rule of Law: History, Politics, Theory (Cambridge: Cambridge University Press, 2004) 36.

${ }^{19}$ Collis, Trials in Burma, 221. 
${ }^{20}$ Collis, Into Hidden Burma: An Autobiography (London: Faber and Faber, 1953) 44.

${ }^{21}$ Collis, Into Hidden Burma, 165.

${ }^{22}$ Orwell, Letter to F. Tennyson Jesse, March 4, 1946 (XVIII: 126). The chief functions of a senior police officer are investigating, inspecting, and reporting, and this may have some bearing on what Orwell thought of, here and elsewhere, as his documentary style.

${ }^{23}$ In 1923, in implementation of the Government of India Act (1919), a form of limited self-rule known as dyarchy had been introduced to British India and Burma.

${ }^{24}$ Hussain, The Jurisprudence of Emergency, 6.

${ }^{25}$ The villainous and wily U Po Kyin, Sub-divisional Magistrate of Kyauktada, does not serve the interest of the British, and does not uphold the law, but corrupts it. Still, his own interests coincide with the maintenance of British government of Burma, in which he thrives.

${ }^{26}$ Orwell, Letter to Charles Doran, November 26, 1938 (XI: 239).

${ }^{27}$ Two years after his return to Europe, E. A. Blair in 1929 wrote that the British were stealing from Burma in two ways: "In the first place, they pillage her natural resources; secondly, they grant themselves the exclusive right to sell her the manufactured products she now needs.” Orwell, "How a Nation is Exploited: The British Empire in Burma" (X:147.) Leonard Woolf remembered his experience as a Colonial Service officer in Ceylon in Growing: An Autobiography of the Years 1904 to 1911 (London: Hogarth Press, 1961).

${ }^{28}$ This is a rather tactless observation of Flory's, since most of the money-lenders in British Burma were Indians.

${ }^{29}$ A nineteenth-century strategic argument that possession of Burma gave the British a buffer against threats to India from the French in Indochina soon lost whatever persuasiveness it had had. But later, as it turned out, Burma played an important part in keeping the Japanese out of India.

${ }^{30}$ Furnivall, Colonial Policy and Practice, 157.

${ }^{31}$ Collis, Trials in Burma, 216. 
${ }^{32}$ Collis, Into Hidden Burma, 166.

${ }^{33}$ Collis, Into Hidden Burma, 177. After interrogation by his employer, the servant, whose name was Ba Chit, had committed suicide. Collis tells the story of the trial and its aftermath in Trials in Burma, 57-82.

${ }^{34}$ The officer, though British, was charged as if he had been any person subject to the law. "But it was hardly thought that he would be tried without special consideration. That was the general assumption.” Collis, Trials in Burma, 189.

${ }^{35}$ Kolsky, ColonialJustice in British India, 186.

${ }^{36}$ Kolsky draws on Burmese as well as Indian cases, including the gang-rape in 1899 of a respectable Burmese woman, Ma Gun, by a group of British soldiers in broad daylight in a Rangoon street. They were all acquitted in a Rangoon court. The victim died the following year. Kolsky, ColonialJustice in British India, 200-03.

${ }^{37}$ Orwell, The Road to Wigan Pier (London: Secker and Warburg, 1987) 138.

${ }^{38}$ Orwell, Letter to F. Tennyson Jesse, March 14, 1946 (XVIII: 128).

${ }^{39}$ Ashis Nandy, The Intimate Enemy: Loss and Recovery of Self under Colonialism (Delhi: Oxford University Press, 1989).

${ }^{40}$ Orwell, The Road to Wigan Pier, 132-33.

${ }^{41}$ "The explicitly racial discourse espoused by critics and perpetrators of white violence in India about how 'blacks' and 'niggers' should be treated reveals continuities in racial attitudes and actions across the British empire, from the eighteenth-century slave plantations on Britain's Caribbean colonies to the nineteenth-century British Raj [and beyond].” Kolsky, Colonial Justice in British India, 232-33.

${ }^{42}$ Orwell, The Road to Wigan Pier, 135.

${ }^{43}$ "The army of unalterable law" is the last line of a sonnet by George Meredith, "Lucifer in Starlight", which Eric Blair read when he was a schoolboy and which "seemed to strike a sort of 
leaden echo in [his] heart". He talks about the phrase (which recurs in his own work) in "Such, Such were the Joys” (XIX:379).

${ }^{44}$ E. M. Forster, A Passage to India, 1924, ed. Oliver Stallybrass (Harmondsworth: Penguin, 1985) 171.

${ }^{45}$ This is simply due process: the City Magistrate is Adela Quested's fiancé, so his Deputy presides at the trial. In this case the accused is Indian, the apparently injured party an Englishwoman. But the likelihood of Indian judges presiding at the trial of Europeans was what had scandalized the Anglo-Indian opponents of the reforms proposed in the Ilbert Bill in 1883, the first of a long series of struggles against legal reform in British India. See Sarvepalli Gopal, The Viceroyalty of Lord Ripon (London: Oxford University Press, 1953).

${ }^{46}$ While it had its source in the common law of England, martial law was proclaimed only in colonial areas. See Hussain, The Jurisprudence of Emergency, 99-132.

${ }^{47}$ Orwell, Nineteen Eighty-Four (London: Secker and Warburg, 1986) 8. Subsequent references to this novel are indicated parenthetically in the text as $\mathbf{N E F}$. The absence of law in Oceania instantiates a state of mind Orwell had diagnosed in his essay "Rudyard Kipling" as early as 1942. "No one, in our time, believes in any sanction greater than military power; no one believes that it is possible to overcome force except by greater force. There is no 'law', there is only power." (XIII:152).

${ }^{48}$ One of Hitler's first acts on coming to power in Germany was to proclaim a Decree for the Protection of the People and the State, an emergency powers law which suspended constitutional guarantees of personal liberties. The Decree was never repealed. The English "state of emergency" is the French "state of siege [état de siège]" and the German and Italian "state of exception [Ausnahmezustand, stato di eccezione]". Giorgio Agamben has argued that "the voluntary creation of a permanent state of emergency" has become "one of the essential practices of contemporary states," and, elegantly, that "the state of exception has by now become the rule". Giorgio Agamben, State of Exception, trans. Kevin Attell (Chicago: University of Chicago Press, 2005), 2, 9. 
${ }^{19}$ See Firas A. J. Al-Jubouri, “The End was Contained in the Beginning': Orwell's Kyauktada and Oceania”, George Orwell Studies 1 (2016), 73-88, and the chapter on "The Shadow of Imperialism" in Stephen Ingle, The Social and Political Thought of George Orwell: A Reassessment (Oxford: Routledge, 2006), 28-45.

${ }^{50}$ The opening pages of Forster's $A$ Passage to India (29-30) scrupulously map these demarcations in the town of Chandrapore. The transgression of such boundaries is the novel's theme.

${ }^{51}$ Edward W. Said, Orientalism (London: Penguin, 1991) 231.

${ }^{52}$ Described here as a war film, it is later referred to as a "news film" (NEF 167), and is probably the Oceanian equivalent of an actuality "newsreel", which often preceded the main feature in cinemas.

${ }^{53}$ In an earlier version, Orwell had written: "All war films. One very good one of a ship full of refugees being bombed somewhere in the Mediterranean. It was full of Jews. The Party lowdown was that we gave them a safe conduct and then sent a torpedo plane after the ship and sank it.” George Orwell: Nineteen Eighty-Four: The Facsimile of the Extant Manuscript, ed. Peter Davison (San Diego: Harcourt Brace Jovanovich, 1984) 27-29.

${ }^{54}$ British policy was to keep Jewish immigration to Palestine, under the British Mandate, to 1,500 per month, and this sometimes involved naval interception of vessels suspected of carrying illegal immigrants when they entered Palestinian territorial waters. See Fritz Liebreich, Britain's Naval and Political Reaction to the Illegal Immigration of Jews to Palestine 1945-48 (London: Routledge, 2005). See also the review of this book by Walid Khalidi, Journal of Palestine Studies 35:4 (Summer 2006) 63-68.

${ }^{55}$ Orwell frequently resorts to this cinematic trope, which is an important resource of the language of Winston's inner life. For example: "Instead of anything directly connected with O'Brien or the Brotherhood, there came into his mind a sort of composite picture of the dark bedroom where his mother had spent her last days, and the little room over Mr Charrington's shop, and the glass paperweight, and the steel engraving in its rosewood frame.” (NEF 186) 
${ }_{56}^{56}$ The final appearance of the Madonna-and-child group is a brutal travesty. In the police cells beneath the Ministry of Love where Winston is awaiting interrogation, an obese drunken women is brought in, collapses on Winston's lap in an inversion and parody of the Pietà, vomits on his shoes, and, discovering they are both named Smith, declares that she might be his mother (NEF 239-10).

${ }^{57}$ See his essay “Anti-Semitism in Britain” (XVII:64-70). While sympathetic to the Jewish cause, Orwell also cautioned that readers of Zionist and pro-Zionist literature should always be aware "that there is also an Arab viewpoint, and, owing to the fact that the Arabs have little footing in the Press outside their own country, it seldom gets a hearing". "Review of ... Land of Promise by Walter Clay Lowdermilk” (XVI:470).

${ }^{58}$ Eurasia and Eastasia, with their Oriental populations, are super-states roughly equal in power to Oceania. "Between the frontiers of the super-states, and not permanently in the possession of any of them, there lies a rough quadrilateral with its corners at Tangier, Brazzaville, Darwin and Hong Kong, containing within it about a fifth of the population of the earth.” (NEF 194-95) This quadrilateral, forever fought over by the powers, is the real Orient of the novel.

${ }^{59}$ For example NEF 15, 121,156. Martin, O’Brien's confidential servant, also has a "Mongolian face" (NEF 181).

${ }^{60}$ The squatting posture may recall the Burmese prisoners in the prison yard, noticed at the end of "A Hanging" (X:210), and "the wretched prisoners squatting in the reeking cages" remembered in The Road to Wigan Pier (136). 